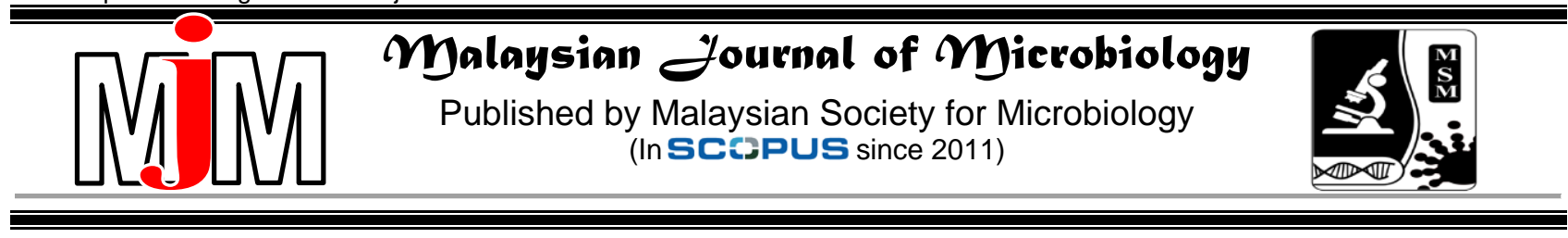

\title{
Extreme environment: Biofilms and microbial diversity
}

\author{
Marwan Jawad Msarah*, Mohd Faiz Mohd Yusoff, Siti Nurema Syahira Samion, Pranesha Prabhakaran, \\ Izyanti Ibrahim and Wan Syaidatul Aqma*
}

\author{
School of Biosciences and Biotechnology, Faculty of Science and Technology, Universiti Kebangsaan Malaysia, 43600 \\ Bangi, Selangor, Malaysia. \\ Email: syaidatul@ukm.edu.my; marwan_masar21@yahoo.com
}

Received 31 October 2017; Received in revised form 19 April 2018; Accepted 27 June 2018

\begin{abstract}
Extreme environments have been the interest of numerous studies and scientific publications. For many years, these environmental roles, which are characterised by high or low temperatures, high-pressure, low $\mathrm{pH}$, high salt concentrations and companions of two or more extreme parameters. For many years, these environmental niches have increased in importance due to extreme microorganisms diversity and their potential returns of several industrial production processes concerning the food fields, medical and pharmaceutical. At present, it's possible to detect life in most extreme environments, from the deep sea hot springs, depth of the oceans, deep inside the earth crust, harsh chemical environments, and high radiation environments through metagenomics analysis. In this review, newly identified microorganisms, and their potential uses in several applied fields have been outlined. The microbial development in biofilms form has supported the survival of alkaliphiles, psychrophile, halophile thermophile and extremophile microorganisms; where they flourish due to the adaptation strategies involving complex variation in biofilms structure and behaviours.
\end{abstract}

Keywords: Biofilms, biodiversity, extreme environments

\section{INTRODUCTION}

Microorganisms are characterised as a simple structure creatures which can be single cell or multicellular when associated to higher organisms and cannot be seen by the naked eyes but only with the aid of microscope. They include bacteria, protozoa, archaea certain algae and fungi. Microorganisms are capable of complex variation in structure and behaviours to enable them to survive in a variety of strict environments. Extremophiles are bacteria and archaea that are adapted and modified to grow under those strict conditions and can be found in a variety of environments such as; hot springs, depth of the oceans, deep inside the earth crust, harsh chemical environments, and high radiation environments because they have a specific adaption capabilities that make them survives in these strict environments. Microbes naturally grow on natural or artificial surfaces. Biofilms can be seen as an excellent model system for studying the microbial development. Biofilms comprise of single microbe or multiple microbial species and can be defined simply and broadly as; populations of microorganisms that are attached together as a group to a surface. According to O'Toole et al. (2000) bacteria that live in natural aquatic environments, are mostly not permitted to float but rather to grow as multi species societies which attached to submerged surfaces. Biofilm formation, its role and effect in specific environment has been studied for a variety of bacterial species, as it plays a significant role in the pathogenicity of bacteria. A most common form of biofilms is a result of some stress. Therefore, biofilms are found in many extreme environments and according to Donlan and Costerton (2002) basically bacteria can form biofilms in whatever ecosystem they inhabit and in a similar manner.

\section{Biofilms}

In nature, bacteria rarely exist as individuals in the harsh environments of constant pressure and fatal stress. To survive in such extremities, these microscopic organisms have adapted a manner of socialisation, where instead of surviving the hardship by oneself; they acted together as a whole community to put up against the treacherous environments that nature has to offer. As a community, the members of the group would have a better chance to respond and adapt to any changes in order to ensure their viability (Marrón-Montiel et al., 2006). In this way, many complicated and highly difficult tasks can be performed due to their increased complexity of structure, similar to those multicellular organisms that perform various life processes (Brenner et al., 2008). 
According to Donlan and Costerton (2002), biofilm defined as the association of multiple species of bacteria that assembled together as a whole community; described as the phenomenon where cellular bindings happen in an aggregation manner and attached together by the secretion of extracellular polymeric substances (EPS), and this community is glued to a foundation surface. The EPS form a matrix that consists of various cellular and non-cellular materials, for instances, small debris or particles, mineral crystals, and so on, but depending on the nature of the environment (Davey and O'toole, 2000). Thus, such processes involve the reciprocal action of both cell-to-cell and cell-to-surface that work in a dynamic system (Kostakioti et al., 2013; Sadekuzzaman et al., 2015). In addition, due to the resilience of the biofilm, this layer of biomaterial may form on diverse and countless types of surface, including intravenous medical devices, plumbing systems, walls, as well as living tissues (Donlan and Costerton, 2002).

The construction of this layer of biomaterials would allow the transition from an individualistic condition to a more provisional communal behaviour that aids tremendously to their survival in extremities of the natural environment (Watnick and Kolter, 2000). In nature, the biofilm is triggered to be constructed in stress and changes induced responses, where the newly formed microenvironment is no more favourable to enhance the microbial growth (Bridier et al., 2011). Under these factors, the responses would entail various networks of regulation, where alterations in gene expression would eventuate the prompts reorganisation of the microbial cells, and subsequently, lead to the modification of the cellular surface, the utilisation and acquisition of nutrients, the virulence factors, as well as other characteristics that enhance their chance of surviving (Hibbing et al., 2010). Within the biofilm structure, however microbial growths are being slowed down a bit, due to the properties of the film (López et al., 2010). The biofilm is chiefly made up of over $90 \%$ of EPS that form the matrix of the whole microbial structure and greatly varies depending on growth conditions, medium, and substrates (López et al., 2010; Karunakaran et al., 2011). Relatively, these substances would simply be defined by a general term for extracellular components that can be found projected or imbedded within the microbial cell wall, which comprises of assorted components, e.g. macromolecules such as polysaccharides and proteins (Karunakaran et al., 2011). The massive secretion of the EPS which form most of the biofilm structure would also be a barrier of diffusion to small molecules required for bacterial growth. As this barrier limits the movement and distribution of molecules, including nutrients, some parts of the community are rendered inactive in term of their metabolic processes. In addition, even though the biofilm is considered as a harmonious collection of bacteria working together as a community, it is also a fact that they are confined and crammed in a tight and limited space, which eventually create a phase similar to a normal bacterial stationary growth. Nevertheless, within the small confined spaces, the biofilm would also permit the expansion of resistant cells within the structure, thus aiding the community as a whole to face the environment. Having the resistant cells within the biofilm, the community would eventually gain a similar to 'herd immunity' manner, where their sensitivities are lowered with the presence of bacteria of enhanced resistance level. Thus, this bio-architectural, structure is highly regarded as a mechanism for the community to ward off any potential hazard from the environment (López et al., 2010).

As discussed earlier, the formation of biofilm is triggered when there are changes in the environment of the bacteria, which signify that environment, is becoming more and more unfavourable for their growth, and consequently, signal the bacteria to alter their metabolic pathway regulations. Once the molecules reach a certain threshold of concentration that is sufficient enough, a series of cascade reaction is activated that leads directly to the starting of a bacterial communication within the community, also known as quorum sensing, which involves cellular coordination's using signal molecules as the messenger of information's (López et al., 2010; Sadekuzzaman et al., 2015). This cellular coordination would eventually control a significant number of processes that involve in the development of the biofilm (López et al., 2010)

The formation of biofilm is a rather dynamic and complicated process, as this layer of organic materials is composed of a various building blocks that are well integrated with one another to form the complex structure. The architectural formation of the biofilm is largely dependent on matters such as the substratum or the foundation of the biofilm, the medium of the environment, the intrinsic attributes of the cells, the type of molecules used in the signalling processes, the type and rate of cellular metabolism, as well as the genetic factors of the microbes (Stewart and Franklin, 2008). The development of the film starts off with an acclimation of a surface, with layers of organic or inorganic matter form on the surface. Subsequently, the acclimation of this surface allows the microorganisms to colonise and habituate on the surface. This is due to the altered surface properties of the substratum, which previously was unfavourable for the microbes to stick around. As the surface becomes more favourable for the colonisation of bacteria, the microorganisms are thus able to form a preliminary reversible attachment with the surface through weak interactions such as Van der Waals interactions (Watnick and Kolter, 2000; Kostakioti et al., 2013; Sadekuzzaman et al., 2015).

As more and more cells accumulate, multiple cellular attachment structures such as flagella and fimbriae would eventually form an irreversible and permanent fixation on the surface, through stronger interactions (hydrophobic/hydrophilic) (Characklis and Cooksey, 1983). The next event that follows would be the propagation and the production of the extracellular polysaccharide (EPS) matrix by the community. This matrix is mainly composed of proteins, polysaccharides, and extracellular deoxyribonucleic acid (DNA), which, as the matters begin to build up and accumulate, 
consequently leads to the establishment and expansion of the biofilm structure (Davey and O'toole, 2000). As the biofilm expands, it would later become matured as water channels formed within the structure are able to, with full efficacy, circulate and deliver nutrients and other signalling molecules to every living cell (Percival et al., 2011). Once triggered due to intrinsic or extrinsic factors, the biofilm rigid structure would begin to loosen up, and the cells start to detach and disperse (either individually or in clumps). The dispersion allows the cells to propagate to other newly-conditioned surfaces, and begin the colonisation process all over again (Watnick and Kolter, 2000; Kostakioti et al., 2013; Sadekuzzaman et al., 2015). Figure 1 visualise the overall process of biofilm formation.

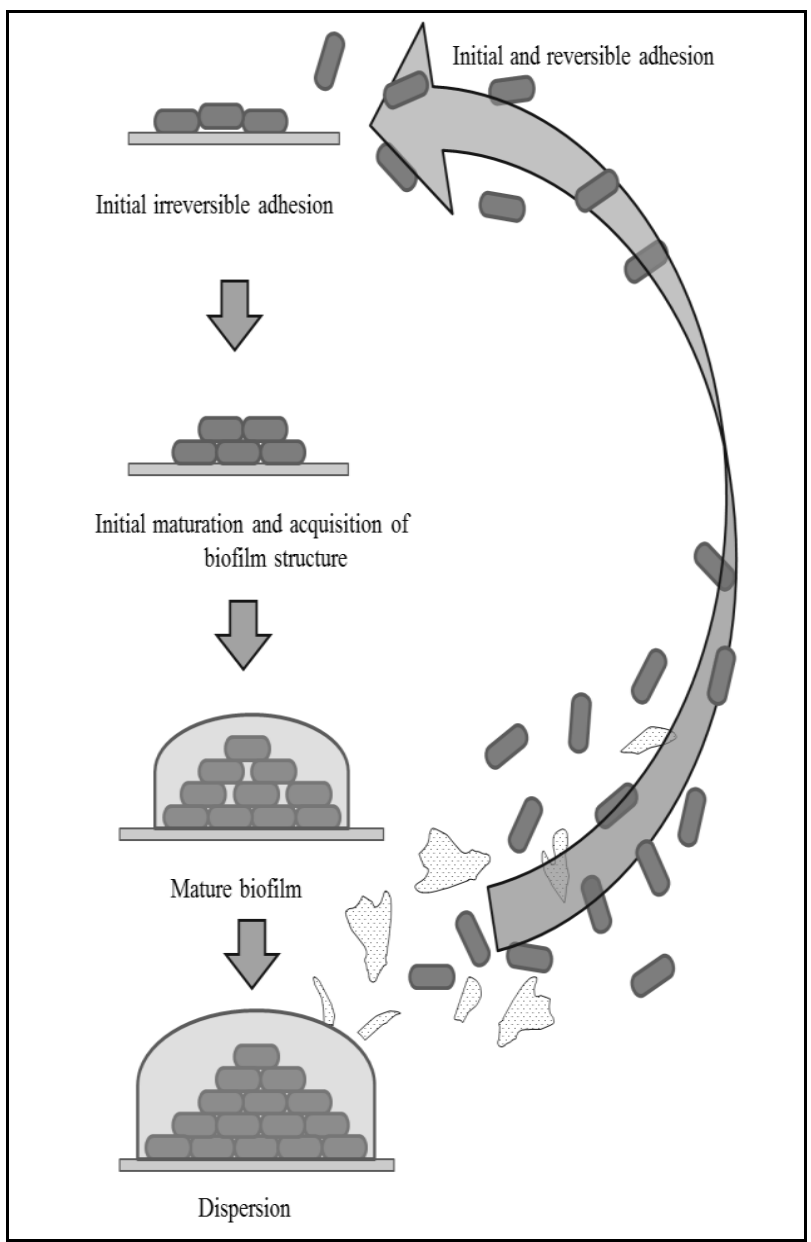

Figure 1: The formation of biofilms.

The EPS has therefore been regarded as a cornerstone for the triumph of bacterial colonisation via biofilm formation, where such secretion is amongst the greatest core factors that make the construction possible. However, till today, little is still known about the complex interaction within the secretion that generates the stable matrix. Yet, it is conceptualised that the interactions would involve various forms of interaction that interlinked with one another; through Van der Waals interaction, polar interactions, electrostatic forces and hydrogen bonding that influences the mechanical stability of the biofilm. A process coined as polymer bridging, also aided the process by allowing the EPS molecules to negate the electrostatic repulsion between the foundation surface and the bacteria. This results in the attachment of the bacteria to the surface, in a more permanent manner (Karunakaran et al., 2011).

\section{Extreme environments}

Extreme is a virtual term, which is viewed as different or obits to what is normal for human beings. A large numbers of microbes inhabit different kinds of extreme environments. Extreme environments according to Skirnisdottir et al. (2000) contain many elements high temperature, $\mathrm{pH}$, pressure, salt concentration, nutrient concentration, water availability, and also conditions having elevated levels of radiation, harmful heavy metals and toxic compounds. Table 1 throws light on extreme environment where biofilms formed.

\section{Biofilm in osmotic stress}

Research show that $99 \%$ of bacteria in nature are attached on a surface in the form of biofilm organization and this helps them bacteria to increase their resistance towards various antimicrobial agents (Parsek and Singh, 2003). Besides that, growth within a biofilm seems to help most species of bacteria to induce a general stress response by protecting their cell from environmental stress (Mah and O'Toole, 2001). Single cell microorganisms are more vulnerable to environmental stress including osmotic shock, since they are directly exposed to their environment ( $\mathrm{Ho}, 2006)$. Osmolarity is used to define the number of solute molecules per solution volume or solution weight. Osmolarity also can be referred as osmolality which describe the osmotic pressure exerted by a given solution (Caon, 2008). This osmotic pressure influenced by the total number of particle or solutes (osmolyte) contain in the solution. According to $\mathrm{Ho}$ (2006) in a biological systems changes in osmolyte concentration occurring either within or outside the cell can thus lead to the very rapid flow of water across the plasma membrane and marked alterations in cell volume. Semipermeable membranes facilitate the separation of two solutions with varied compositions.

The ability to regulate and preserve distinct intracellular and extracellular solute micro environments is crucial in maintaining cellular homeostasis. Exposure of a cell to hypertonic environment in which the osmolality outside the cell is greater than that present within the cell results in the osmotic efflux of water, a reduction in cell volume (cell shrinkage) and an increase in the concentration of all intracellular constituents. The resulting biochemical disequilibrium gives rise to a wide spectrum of deleterious effects on cell function and, in the event biochemical homeostasis is not restored, ultimately results in apoptotic cell death (Proft and Struhl, 2004). 
Osmotic stress specifically hyper-osmotic stress always related to microorganism that live at a high salinity environment for example marine ecosystem. Moderate halophiles are defined as organisms having higher growth rates in media containing between $0.5 \mathrm{M}$ and $2.5 \mathrm{M} \mathrm{NaCl}$, while extreme halophiles have higher growth rates in media containing over $2.5 \mathrm{M} \mathrm{NaCl}$ (Ventosa et al., 1998). Seawater divided into three components, firstly water which act as solvent, secondly dissolve substance which is salt ion also known as solutes and minor to trace amount of dissolve metals, nutrients, gases and inorganic compound. Solute concentration in seawater play an important role in determining the salinity of the seawater. Unit for salinity of seawater called parts per thousand represented by symbol (\%o). Average or normal salinity of seawater is $35 \%$. The most abundantly dissolved ions in seawater are sodium, chloride, magnesium, sulfate and calcium and its osmolarity is about $1000 \mathrm{mOsm} / \mathrm{L}$ (Tada et al., 1998). Concentration of this solutes in seawater also play some important roles in the osmoregulation of the microbial cell.

\section{Biofilm in Cold Environment}

Amongst all of the major environmental stresses, temperature would be the one that is considered to be imposed on all living organisms regardless of their niche in the ecosystem (Aguilar et al., 2001). The majority of the Earth's biosphere is locked in a permanent cold condition, with the temperature dropped below $5{ }^{\circ} \mathrm{C}$. Such low temperature would simply be considered as one of the most common 'extreme' environment, as it is unsustainable for most organisms' growth. However, such niches are usually filled by peculiar microorganisms that are resistant to the level of extremities, making the psychrophiles as the most diverse and extensively distributed extremophiles (De Maayer et al., 2014). These hardy microorganisms that belong to psychrophilic and psychrotrophic groups are crucial in the global ecology, as most of the terrestrial and aquatic ecosystem of the earth is constantly or periodically frozen in the extreme cold temperature. For an instance, the polar region made up of $14 \%$ of the earth; if included with alpine soils and lakes, fresh waters and caves, snow and ice fields, approximately $80 \%$ and more of the earth biosphere associated with the temperature that is below $5{ }^{\circ} \mathrm{C}$ (Hébraud and Potier, 1999). Psychrophiles are easily defined as microbes that able to grow at an optimal temperature for growth of about $15^{\circ} \mathrm{C}$ or below, with utmost growth temperature of about $20^{\circ} \mathrm{C}$; and the capability to grow at $0{ }^{\circ} \mathrm{C}$. This group of extremophiles mainly belongs to the Gram-negative Proteobacteria (Groudieva et al., 2003). On the other hand, the psychrotrophs are those that typically have optimum and the maximum growth temperature of $20{ }^{\circ} \mathrm{C}$ or above, where the bacteria are able to adapt to temperature downshifts with a lag period prior to growth resumes at a rate characteristic of the new temperature (Hébraud and Potier, 1999).
As a physical stress, cold can alter physiochemical parameters of a living cell by interfering and affecting enzyme kinetic, flexibility, water viscosity, cell integrity, activation of membrane-associated sensor, macromolecules interaction and enzyme kinetic, as well as solute diffusion rates, membrane fluidity and conformation, topology and reciprocal interaction of macromolecules including proteins, DNA and RNA as temperature could affect interior of cells rapidly (Hébraud and Potier, 1999; Gualerzi et al., 2003; Margesin and Miteva, 2011; De Maayer et al., 2014). Cellular function such as protein synthesis (transcription, translation), RNA and protein folding (as adaptation strategic at molecular structure of protein to increase flexibility) and uptake of cryoprotein (EPS) are induced (Margesin and Miteva, 2011). Alterations in the membrane composition due to temperature are mediated by de novo synthesis of specific enzyme following temperature downshift, and enzyme activation that is crucial for modification of pre-existing lipids (Hébraud and Potier, 1999). Membrane fluidity is reduced to maintain optimum fluidity by integrating fatty acids of lower melting point (including unsaturated, branched-chain or short-chain fatty acids) into the membrane lipids, at the same time increases the proportion of anteiso (relative to ISO) and of cis (relative to trans fatty acids) (Fonseca et al., 2011).

Enzymes expressed by these microbes are more thermolabile. However, they are much more active at low temperature. Caps, which are the cold acclimation proteins, will be continuously synthesised during the prolonged growth under low temperature. This protein is assumed to have's vital role for life in the cold realm of the world, and was predicted to be part of the metabolic functions by maintaining the membrane fluidity and/or by replacing the cold-denatured peptides at low temperature. In psychotropic Arthrobacter globiformis SI 55, some caps act as a cold-specific protease that eradicates accumulated denatured proteins that could cause the deleterious effect to the cells (Hébraud and Potier, 1999). Based on a previous study, expression of general stress response sigma factor RpoS increased in both rich and minimal medium when it is exposed to low temperature during the exponential phase. Gene regulation under low temperature $\left(25^{\circ} \mathrm{C}\right)$ is with the action of general stress response sigma factor RpoS and small regulatory RNA DsrA. At low temperature, increased in transcription level of $d s r A$ lead to the interaction of DsrA with the rpoS mRNA to manipulate its secondary structure to enable more efficient translation of rpoS mRNA (White-Ziegler et al., 2008). According to an experiment conducted by Fonseca et al. (2011) using Pseudomonas putida KT2440, transcriptome and proteome profiles of cells grown at 10 ${ }^{\circ} \mathrm{C}$ revealed that approximately 266 genes which made up of $5 \%$ of the genome were modified. Genes that showed differential expression were genes that regulate energy metabolism or in transport and binding of substrate. Under low temperature, there was an increase in protein folding and stability of DNA and RNA secondary structure and reduction in membrane fluidity and growth rate. During adaptation period under such conditions, cold-shock 
Malays. J. Microbiol. Vol 14(5) 2018, pp. 435-443

DOI: http://dx.doi.org/10.21161/mjm.116317

Table 1: Biofilms formation present in a strict environment.

\begin{tabular}{|c|c|c|c|}
\hline Strict environment & Descriptions & Examples & Reference \\
\hline Extremely cold & Below $5^{\circ} \mathrm{C}$ & $\begin{array}{l}\text { Deep ocean habitats, } \\
\text { mountain sites, polar sites. }\end{array}$ & Edwards et al. (2005) \\
\hline Extremely hot & Higher than $40^{\circ} \mathrm{C}$ & $\begin{array}{l}\text { Comparable locations } \\
\text { worldwide or deep-sea vents }\end{array}$ & Allen and McKay (1998) \\
\hline Acidic environments & Below pH 5 & $\begin{array}{l}\text { Mining activity or acid rain, } \\
\text { e.g., The Rio Tinto river }\end{array}$ & Amils et al. (2014) \\
\hline Alkaline environments & $\mathrm{pH}$ higher than 9 & $\begin{array}{l}\text { Natural habitats } \\
\text { Octopus spring }\end{array}$ & Boomer et al. (2009) \\
\hline $\begin{array}{l}\text { Hypersaline environment } \\
\text { (high salt) }\end{array}$ & Seawater, that is, $>3.5 \%$ & $\begin{array}{l}\text { Salt lakes } \\
\text { (e.g., Mono lake) }\end{array}$ & Arp et al. (1999) \\
\hline Under pressure & $\begin{array}{l}\text { Environments under } \\
\text { extreme pressure } \\
\text { (hydrostatic) }\end{array}$ & $\begin{array}{l}\text { Enclosed habitats under } \\
\text { pressure and aquatic habitats } \\
2000 \text { meters deep }\end{array}$ & Edwards et al. (2005) \\
\hline Without water & $\begin{array}{l}\text { Habitats without free } \\
\text { water }\end{array}$ & $\begin{array}{l}\text { Some endolithic habitats and } \\
\text { hot or cold desert } \\
\text { environments. }\end{array}$ & $\begin{array}{l}\text { Edwards et al. (2005); De } \\
\text { Los Ríos et al. (2007) }\end{array}$ \\
\hline Without oxygen & Without free oxygen & Habitats in deeper sediments & Meyer-Reil (1994) \\
\hline Altered by humans & $\begin{array}{l}\text { Organic compounds and } \\
\text { heavy metals. }\end{array}$ & $\begin{array}{l}\text { Geothermal system, mine } \\
\text { tailings, oil impacted habitats. }\end{array}$ & Osvald et al. (2016) \\
\hline Outer space & $\begin{array}{l}\text { Addresses life beyond the } \\
\text { known biosphere }\end{array}$ & Mars & Allen and McKay (1998) \\
\hline
\end{tabular}

Table 2: Common organisms found in a different kind of hot springs.

\begin{tabular}{|c|c|c|c|}
\hline Hot springs & Location & Common organism & Reference \\
\hline $\begin{array}{l}\text { Hot Springs Above } \\
\text { Sea Level }\end{array}$ & Center and East of Tibet & Thaumarchaeota & Huang et al. (2011) \\
\hline Alkaline Hot Spring & USA (Octopus YNP) & Thermophilic bacteria & $\begin{array}{l}\text { Coman et al. (2013); } \\
\text { Meyer-Dombard et al. } \\
\text { (2005) }\end{array}$ \\
\hline Acidic environments & $\begin{array}{l}\text { Iberian Pyritic Belt } \\
\text { southern Spain (Rio } \\
\text { Tintio River) }\end{array}$ & $\begin{array}{l}\text { Iron-oxidizing bacteria and sulfur- } \\
\text { oxidizing bacteria, alkaliphilic }\end{array}$ & $\begin{array}{l}\text { Fernández-Remolar et } \\
\text { al. (2003) }\end{array}$ \\
\hline Hypersaline (high salt) & $\begin{array}{l}\text { North America } \\
\text { (Mono Lake) }\end{array}$ & Halophiles and alkaliphiles & $\begin{array}{l}\text { Rothschild and } \\
\text { Mancinelli (2001); Kulp } \\
\text { et al. (2008) }\end{array}$ \\
\hline \multirow[t]{3}{*}{ Hot water springs } & $\begin{array}{l}\text { India (Manikaran, } \\
\text { Himachal Pradesh) }\end{array}$ & Cyanobacteria & Mongra (2012) \\
\hline & $\begin{array}{l}\text { Malaysia (The Sungai } \\
\text { Klah) (SK) }\end{array}$ & $\begin{array}{l}\text { Aquificae, Thermodesulfobacteria, } \\
\text { Deinococcus-Thermus, Thermotogae, } \\
\text { Chloroflexi, Dictyoglomi. }\end{array}$ & Chan et al. (2015) \\
\hline & $\begin{array}{l}\text { Thailand (Bor Khlueng } \\
\text { Hot Spring) }\end{array}$ & $\begin{array}{l}\text { Large diversity Acidobacteria, } \\
\text { Bacteriodetes, Cyanobacteria }\end{array}$ & $\begin{array}{l}\text { Kanokratana et al. } \\
\text { (2004) }\end{array}$ \\
\hline Acidic hot springs & Iceland (Solfatara fields) & Acidophiles & $\begin{array}{l}\text { Rothschild and } \\
\text { Mancinelli (2001) }\end{array}$ \\
\hline Mesophilic hot springs & $\begin{array}{l}\text { Western Plain of } \\
\text { Romania }\end{array}$ & $\begin{array}{l}\text { Proteobacteria and Cyanobacteria, } \\
\text { Chloroflexi }\end{array}$ & Coman et al. (2013) \\
\hline Icelandic hot springs & Iceland & Acidophilic, Thermophilic & Krebs et al. (2014) \\
\hline $\begin{array}{l}\text { New Zealand hot } \\
\text { Springs }\end{array}$ & Around New Zealand & Sulfolobus & Ellis et al. (2005) \\
\hline Geothermal springs & $\begin{array}{l}\text { Algeria (El Bibanes, } \\
\text { Essalihine Hot Springs) }\end{array}$ & $\begin{array}{l}\text { Cyanobacteria, Gloeocapsopsis, } \\
\text { Gloeocapsa, Stigonema, Fischerella }\end{array}$ & $\begin{array}{l}\text { Amarouche-Yala et al. } \\
\text { (2014) }\end{array}$ \\
\hline $\begin{array}{l}\text { Above sea level hot } \\
\text { springs }\end{array}$ & $\begin{array}{l}\text { Central and eastern } \\
\text { Tibet }\end{array}$ & Thaumarchaeota & Huang et al. (2011) \\
\hline
\end{tabular}


proteins are highly expressed, at the same time majority of protein synthesis will be reduced dramatically. The cold-shock proteins that were highly produced increase stability and preferential translation of the corresponding mRNAs (Fonseca et al., 2011). Cold-shock response in psychrophiles does not suppress the synthesis of housekeeping protein, at the same time proteins involved in cold-shock response increase with severity of the coldshock (Margesin and Miteva, 2011).

Manipulation of microbial physiological feedback reaction their specific niches and cell-to-cell interaction could by environmental or external stimuli that induce corresponding genetic and regulatory circuits throughout development of biofilm. This condition causes differences in biofilm structure and compositions (Lee et al., 2014). Based on the study conducted by Groudieva et al. (2003) Psychromonas arctica sp. formed a multi-layered biofilm at any cultivation temperature from $4{ }^{\circ} \mathrm{C}$ to $20{ }^{\circ} \mathrm{C}$ independent of the carbon source used just within few days (De Maayer et al., 2014). In addition to that, trancriptomic analysis of Escherichia coli K-12 MC4100 proved that almost $7 \%$ of the genome (297 genes) are majorly expressed at $23{ }^{\circ} \mathrm{C}$ when compared to growth at $37{ }^{\circ} \mathrm{C}$, where $40 \%$ of the genes are preferentially expressed at $23{ }^{\circ} \mathrm{C}$ are RpoS-controlled genes indicating that low temperature could provoke the general stress response. Two categories of genes that worth noticing are those related with cold and biofilm development (WhiteZiegler et al., 2008). Kamjumphol et al. (2013) also stated that biofilm formation by Bulkhoderia pseudomalle induced by low temperature $\left(20^{\circ} \mathrm{C}\right)$ as it triggers bacterial general stress responses. While in Hafnia alvei, biofilm formation increase dramatically at $25{ }^{\circ} \mathrm{C}$ compared to 37 ${ }^{\circ} \mathrm{C}$ even though $\mathrm{H}$. alvei is an opportunistic pathogen of animal and humans. With its psychotropic behavior, Listeria monocytogenes known as one of the pathogens that is linked to major outbreaks in food products due to its ability to replicate under cold environment. Typically, $L$. monocytogenes strains are capable of forming biofilm of higher level with more extracellular polysaccharides compared to weak biofilm producers. Growth temperature and the phase of growth could manipulate the cell wall composition. Thus, altering surface electrical properties, electron donor or electron acceptor character of the bacteria and hydrophobicity. L. monocytogenes become highly hydrophobic under freezing temperature indicating an alteration in cell wall composition as some bacteria preserve cell wall lipid composition with temperature and cell growth. Based on this study, it has been proven that initial adherent population increased during freezing incubation thus increasing the hydrophobicity of the cells (Slama et al., 2012).

Extracellular matrix in a biofilm may act as a supplementary survival mechanism in the natural environment under starvation conditions, by defending the cells from frost and managing the nutrient supply inside the multispecies biofilm community. Antifreeze or icebinding (AFP) proteins produced by psychrophiles binds to and control the ice crystal formation and recrystallization by lowering the freezing point (De Maayer et al., 2014). Cold-adapted microorganism typically produces a high amount of EPS to aid in adhesion to the wet surface and formation of biofilm, entrap nutrients, mediate biochemical interaction, and protect cells against unfavorable environmental conditions (Margesin and Miteva, 2011). EPS produced, acts as a potential psychrophiles under cold condition, as it lowers the freezing point and ice nucleation temperature of water due to its high polyhydroxy content. The EPS also plays the crucial role in facilitating surface adhesion, cellular aggregation and biofilm formation; at the same time protects the extracellular enzymes against cold denaturation and autolysis (De Maayer et al., 2014). In addition to that, a study conducted using Pseudoalteromonas sp. Sm9913 that has been isolated from $1855 \mathrm{~m}$ of the deep-sea sediment, which showed an increase in the EPS production at a decreasing culture temperature within the range of $10-30^{\circ} \mathrm{C}$. The structure is consisted of a linear arrangement linkage of glucose with a high degree of acetylation. Besides that, EPS also aids in the survival of psychrophilic microbes in the permanently cold environment.

As a community, living in aggregates can also be beneficial to marine bacteria as adherent to other cells surface allows interaction and nutrient uptake. For these bacteria, the EPS would provide the role of cryoprotectant in this environment of high salinity and low temperature. The EPS production by psychro-tolerant bacteria, on the other hand, is believed to play the crucial role in sea ice microbial communities. This is due to the fact that the bacterial EPS production in the deep cold ecosystem would provide a protective barrier to these microorganisms (Poli et al., 2010). Montgomery et al. (2013) also stated that analysis of psychrophile Psychromonas ingrahamii, showed the presence of an orthologue of $L u x R$ that believed to have a crucial role in biofilm formation, where this microbe is found in the seaice. The production of EPS thus enables this microbe to lower the freezing point in the surrounding environment, while at the same time enhances the availability of water for its growth.

In order to survive such extreme condition, microbes undergo structural and functional evolution in order to adapt to low temperature condition. Under low temperature, the membrane becomes more inflexible, followed by activation of membrane-associated sensor. Transduction of signal to response regulator leads to upregulation of genes that take part in membrane fluidity modulation and cold adaptation (Davey and O'toole, 2000). Cellular function such as protein synthesis (transcription, translation), RNA and protein folding as an adaptation at molecular structure of protein to increase flexibility. Cold-active enzymes that produced by psychrophiles are more functional at lower temperature and moderate temperature compared to their mesophilic homologues. The cold-shock response in pyschrophiles does not suppress the synthesis of housekeeping protein, at the same time proteins involved in cold-shock response increase with severity of the cold-shock. Cold-adapted microorganism typically produces high amount of EPS to 
aid in adhesion to wet surface and formation of biofilm,entrap nutrients, mediate biochemical interaction, and protect cells against unfavorable environmental conditions (Margesin and Miteva, 2011).

\section{Biofilm at high temperatures}

Thermal springs are considered as of great interest to researchers worldwide among the variety of extreme environments for their diversities of microbial communities. Hot springs are distributed throughout the worlds with different surrounding and they were formed as a result of the movement of hot water from the earth's crust via burdens created by tectonic movement or volcanic eruption. The microbial community who reside within these Hot Springs diversifies (formation of biofilms) and understanding how physicochemical conditions and biological interactions have shaped these microbial societies becomes easier by increasing number of reports (Table 2). Biofilm naturally grows anywhere if there is moisture, apply heat, and a food source, and they will flourish.

Diverse geochemical environments like Yellowstone National Park (YNP) diverse geochemical environments host a variety of chemotrophic and phototrophic thermophilic communities which according to Meyer-Dombard et al. (2005) is an exceptional example of having biofilm pools within the Hot Springs. The environmental factors that furthermost directly influence microbial diversity in hot springs varies and the microbial biofilms commonly occur within the Hot Springs as mats of several centimetres in thickness (often numerous colours). According to Meyer-Dombard et al. (2005) water temperatures regulate the distribution of microbe inside the Hot Springs and generally highly elevated $\left(60{ }^{\circ} \mathrm{C}\right.$ or higher), which limits the microbial life (only Bacteria and Archaea). According to Kulp et al. (2008) the overflow provides constant temperatures and mineral nutrients which allow dense microbial mats to be formed and the inclines of the Hot Springs make it promising for various species with diverse temperature to dwell these areas which result in a diverse microbial flora.

\section{CONCLUSION}

Researchers have known and studied surface-attached bacteria for many years and at least one type of biofilm community (stromatolite-associated microbial mat) is thought to represent a very ancient form of life. Moreover, viewing bacteria from the perspective of different and extreme environments, altering our view of the microbe living there. Given that most microbes from extreme environments cannot be grown under standard laboratory conditions, the development of new technologies metagenomics will open many new research avenues for the discovery of genes through bioinformatics and develop accurate and realistic models of natural communities in the laboratory is one of the keys to studying complex biological systems. Scientists have developed tools for studying biofilm systems and demonstrated remarkable resourcefulness, however, we are only just beginning to fully comprehend the significance of biofilm communities, further, development will certainly be required in this area and that will be one of the challenges in future research.

\section{REFERENCES}

Aguilar, P. S., Hernandez-Arriaga, A. M., Cybulski, L. E., Erazo, A. C. and de Mendoza, D. (2001). Molecular basis of thermosensing: A two-component signal transduction thermometer in Bacillus subtilis. The EMBO Journal 20, 1681-1691.

Allen, C. C. and McKay, D. S. (1998). Biomarkers in Thermal Spring Carbonates: Implications for Mars. 29th Annual Lunar and Planetary Science Conference, Houston, Texas. pp. 1509.

Amarouche-Yala, S., Benouadah, A., Bentabet, A. E. O. and López-García, P. (2014). Morphological and phylogenetic diversity of thermophilic cyanobacteria in Algerian hot springs. Extremophiles 18, 1035-1047.

Amils, R., Fernández-Remolar, D. and IPBSL Team. (2014). Río Tinto: A geochemical and mineralogical terrestrial analogue of Mars. Life 4, 511-534.

Arp, G., Reimer, A. and Reitner, J. (1999). Calcification in cyanobacterial biofilms of alkaline salt lakes. European Journal of Phycology 34, 393-403.

Bridier, A., Briandet, R., Thomas, V. and DuboisBrissonnet, F. (2011). Resistance of bacterial biofilms to disinfectants: A review. Biofouling 27, 1017-1032.

Boomer, S. M., Noll, K. L., Geesey, G. G. and Dutton, B. E. (2009). Formation of multilayered photosynthetic biofilms in an alkaline thermal spring in Yellowstone National Park, Wyoming. Applied and Environmental Microbiology 75, 2464-2475.

Brenner, K., You, L. and Arnold, F. H. (2008). Engineering microbial consortia: A new frontier in synthetic biology. Trends in Biotechnology 26, 483489.

Caon, M. (2008). Osmoles, osmolality and osmotic pressure: Clarifying the puzzle of solution concentration. Contemporary Nurse 29, 92-99.

Chan, C. S., Chan, K. G., Tay, Y. L., Chua, Y. H. and Goh, K. M. (2015). Diversity of thermophiles in a Malaysian hot spring determined using 16S rRNA and shotgun metagenome sequencing. Frontiers in Microbiology 6, 1-15.

Characklis, W. G. and Cooksey, K. E. (1983). Biofilms and microbial fouling. In Advances in Applied Microbiology 29, 93-138.

Coman, C., Drugă, B., Hegedus, A., Sicora, C. and Dragoş, N. (2013). Archaeal and bacterial diversity in two hot spring microbial mats from a geothermal region in Romania. Extremophiles 17, 523-534.

Davey, M. E. and O'toole, G. A. (2000). Microbial biofilms: From ecology to molecular genetics. Microbiology and Molecular Biology Reviews 64, 847867.

De Los Ríos, A., Grube, M., Sancho, L. G. and Ascaso, C. (2007). Ultrastructural and genetic characteristics of endolithic cyanobacterial biofilms colonizing Antarctic 
granite rocks. FEMS Microbiology Ecology 59, 386395.

De Maayer, P., Anderson, D., Cary, C. and Cowan, D. A. (2014). Some like it cold: Understanding the survival strategies of psychrophiles. EMBO Reports e201338170.

Donlan, R. M. and Costerton, J. W. (2002). Biofilms: Survival mechanisms of clinically relevant microorganisms. Clinical Microbiology Reviews 15, 167-193.

Edwards, K. J., Bach, W. and McCollom, T. M. (2005). Geomicrobiology in oceanography: Microbe-mineral interactions at and below the seafloor. TRENDS in Microbiology 13, 449-456.

Ellis, D. G., Bizzoco, R. L. W., Maezato, Y., Baggett, J. N. and Kelley, S. T. (2005). Microscopic examination of acidic hot springs of Waiotapu, North Island, New Zealand. pp. 1001-1011.

Fernández-Remolar, D. C., Rodriguez, N., Gómez, F. and Amils, R. (2003). Geological record of an acidic environment driven by iron hydrochemistry: The Tinto River system. Journal of Geophysical Research: Planets 108, 5080-5095.

Fonseca, P., Moreno, R. and Rojo, F. (2011). Growth of Pseudomonas putida at low temperature: Global transcriptomic and proteomic analyses. Environmental Microbiology Reports 3, 329-339.

Groudieva, T., Grote, R. and Antranikian, G. (2003). Psychromonas arctica sp. nov., a novel psychrotolerant, biofilm-forming bacterium isolated from Spitzbergen. International Journal of Systematic and Evolutionary Microbiology 53, 539-545.

Gualerzi, C. O., Giuliodori, A. M. and Pon, C. L. (2003). Transcriptional and post-transcriptional control of coldshock genes. Journal of Molecular Biology 331, $527-$ 539.

Hibbing, M. E., Fuqua, C., Parsek, M. R. and Peterson, S. B. (2010). Bacterial competition: Surviving and thriving in the microbial jungle. Nature Reviews Microbiology 8(1), 15.

Hébraud, M. and Potier, P. (1999). Cold shock response and low temperature adaptation in psychrotrophic bacteria. Journal of Molecular Microbiology and Biotechnology 1, 211-219.

Ho, S. N. (2006). Intracellular water homeostasis and the mammalian cellular osmotic stress response. Journal of Cellular Physiology 206, 9-15.

Huang, Q., Dong, C. Z., Dong, R. M., Jiang, H., Wang, S., Wang, G. and Zhang, C. (2011). Archaeal and bacterial diversity in hot springs on the Tibetan Plateau, China. Extremophiles 15, 549-563.

Kamjumphol, W., Chareonsudjai, S., Chareonsudjai, P., Wongratanacheewin, S. and Taweechaisupapong, S. (2013). Environmental factors affecting Burkholderia pseudomallei biofilm formation. Southeast Asian Journal of Tropical Medicine and Public Health 44(1), 72-81.

Kanokratana, P., Chanapan, S., Pootanakit, K. and Eurwilaichitr, L. (2004). Diversity and abundance of
Bacteria and Archaea in the Bor Khlueng hot spring in Thailand. Journal of Basic Microbiology 44, 430-444.

Karunakaran, E., Mukherjee, J., Ramalingam, B. and Biggs, C. A. (2011). "Biofilmology": A multidisciplinary review of the study of microbial biofilms. Applied Microbiology and Biotechnology 90, 1869-1881.

Kostakioti, M., Hadjifrangiskou, M. and Hultgren, S. J. (2013). Bacterial biofilms: Development, dispersal, and therapeutic strategies in the dawn of the postantibiotic era. Cold Spring Harbor Perspectives in Medicine 3, a010306.

Krebs, J. E., Vaishampayan, P., Probst, A. J., Tom, L. M., Marteinsson, V. T., Andersen, G. L. and Venkateswaran, K. (2014). Microbial community structures of novel Icelandic hot spring systems revealed by PhyloChip G3 Analysis. Astrobiology 14, 229-240.

Kulp, T. R., Hoeft, S. E., Asao, M., Madigan, M. T., Hollibaugh, J. T., Fisher, J. C., ... and Oremland, R. S. (2008). Arsenic (III) fuels anoxygenic photosynthesis in hot spring biofilms from Mono Lake, California. Science 321, 967-970.

Lee, O. O., Wang, Y., Tian, R., Zhang, W., Shek, C. S., Bougouffa, S., ... and Zhang, X. (2014). In situ environment rather than substrate type dictates microbial community structure of biofilms in a cold seep system. Scientific Reports 4, 3587.

López, D., Vlamakis, H. and Kolter, R. (2010). Biofilms. Cold Spring Harbor Perspectives in Biology 2, a000398.

Mah, T. F. C. and O'Toole, G. A. (2001). Mechanisms of biofilm resistance to antimicrobial agents. Trends in Microbiology 9, 34-39.

Margesin, R. and Miteva, V. (2011). Diversity and ecology of psychrophilic microorganisms. Research in Microbiology 162, 346-361.

Marrón-Montiel, E., Ruiz-Ordaz, N., Rubio-Granados, C., Juarez-Ramirez, C. and Galíndez-Mayer, C. J. (2006). 2, 4-D-degrading bacterial consortium: Isolation, kinetic characterization in batch and continuous culture and application for bioaugmenting an activated sludge microbial community. Process Biochemistry 41, 1521-1528.

Meyer-Dombard, D. R., Shock, E. L. and Amend, J. P. (2005). Archaeal and bacterial communities in geochemically diverse hot springs of Yellowstone National Park, USA. Geobiology 3, 211-227.

Meyer-Reil, L. A. (1994). Microbial life in sedimentary biofilms-the challenge to microbial ecologists. Marine Ecology Progress Series. Oldendorf 112, 303-311.

Mongra, A. C. (2012). Distribution pattern of Cyanobacteria in hot water springs of Tattapani, Himachal Pradesh, India. Journal of Academia and Industrial Research 1, 363-370.

Montgomery, K., Charlesworth, J. C., LeBard, R., Visscher, P. T. and Burns, B. P. (2013). Quorum sensing in extreme environments. Life 3, 131-148.

Osvald, M., Maróti, G., Pap, B. and Szanyi, J. (2016). Biofilm forming bacteria during thermal water reinjection. Geofluids 501, 9231056. 
O'Toole, G., Kaplan, H. B. and Kolter, R. (2000). Biofilm formation as microbial development. Annual Reviews in Microbiology 54(1), 49-79.

Percival, S. L., Malic, S., Cruz, H. and Williams, D. W. (2011). Introduction to biofilms. In Biofilms and Veterinary Medicine 41-68.

Parsek, M. R. and Singh, P. K. (2003). Bacterial biofilms: An emerging link to disease pathogenesis. Annual Reviews in Microbiology 57, 677-701.

Poli, A., Anzelmo, G. and Nicolaus, B. (2010). Bacterial exopolysaccharides from extreme marine habitats: Production, characterization and biological activities. Marine Drugs 8, 1779-1802.

Proft, M. and Struhl, K. (2004). MAP kinase-mediated stress relief that precedes and regulates the timing of transcriptional induction. Cell 118, 351-361.

Rothschild, L. J. and Mancinelli, R. L. (2001). Life in extreme environments. Nature 409, 1092-1101.

Sadekuzzaman, M., Yang, S., Mizan, M. F. R. and Ha, S. D. (2015). Current and recent advanced strategies for combating biofilms. Comprehensive Reviews in Food Science and Food Safety 14, 491-509.

Skirnisdottir, S., Hreggvidsson, G. O., Hjörleifsdottir, S., Marteinsson, V. T., Petursdottir, S. K., Holst, 0. and Kristjansson, J. K. (2000). Influence of sulfide and temperature on species composition and community structure of hot spring microbial mats. Applied and Environmental Microbiology 66, 28352841.

Slama, R. B., Bekir, K., Miladi, H., Noumi, A. and Bakhrouf, A. (2012). Adhesive ability and biofilm metabolic activity of Listeria monocytogenes strains before and after cold stress. African Journal of Biotechnology 11, 12475-12482.

Stewart, P. S. and Franklin, M. J. (2008). Physiological heterogeneity in biofilms. Nature Reviews Microbiology 6(3), 199.

Tada, K., Tada, M. and Maita, Y. (1998). Dissolved free amino acids in coastal seawater using a modified fluorometric method. Journal of Oceanography 54, 313-321.

Ventosa, A., Márquez, M. C., Garabito, M. J. and Arahal, D. R. (1998). Moderately halophilic Grampositive bacterial diversity in hypersaline environments. Extremophiles 2, 297-304.

Watnick, P. and Kolter, R. (2000). Biofilm, City of Microbes. Journal of Bacteriology 182, 2675-2679.

White-Ziegler, C. A., Um, S., Perez, N. M., Berns, A. L., Malhowski, A. J. and Young, S. (2008). Low temperature $\left(23^{\circ} \mathrm{C}\right)$ increases expression of biofilm-, cold-shock-and RpoS-dependent genes in Escherichia coli K-12. Microbiology 154, 148-166. 